\title{
Harapan terhadap Perdamaian: Peran Need for Closure, Fondasi Moral, dan Latar Belakang Demografis
}

\author{
Agus Abdul Rahman ${ }^{1}$, Nur'aini Azizah ${ }^{2}$, Royanulloh $^{3}$ \\ ${ }^{1,2}$ Fakultas Psikologi, Universitas Islam Negeri Sunan Gunung Djati Bandung, Indonesia \\ ${ }^{3}$ Fakultas Ushuluddin dan Humaniora, Universitas Islam Negeri Walisongo, Semarang, Indonesia \\ e-mail: agus.abdulrahman@uinsgd.ac.id
}

\begin{abstract}
This study aims to examine the role of need for closure, moral foundations, and demographic background on hope for peace. The method used was a quantitative survey of 374 students. The measuring instrument consisted of a scale of hope in the context of peace, a scale of need for closure (NFC), and a moral foundation questionnaire (MFQ). The measured demographic background includes age, gender, ethnicity, and affiliation of religious organizations. Data were analyzed using path analysis. Findings from this study indicate that need for closure and moral foundations have a significant direct effect on hopes for peace. There are no differences in hope for peace at different ages, genders, religious organizational affiliations, and ethnicities.
\end{abstract}

Keywords: hope, peace, moral foundation, cognitive closure

\begin{abstract}
Abstrak
Penelitian ini berupaya menguji pengaruh need for closure, fondasi moral, dan latar belakang demografis terhadap harapan untuk perdamaian. Metode yang digunakan adalah survei kuantitatif pada 374 mahasiswa. Alat ukur yang digunakan terdiri dari skala harapan dalam konteks perdamaian, skala need for closure, dan moral foundation questionnaire (MFQ). Latar belakang demografis yang diukur mencakup usia, jenis kelamin, suku, dan afiliasi organisasi keagamaan. Data dianalisis menggunakan analisis jalur. Temuan dari studi ini menunjukkan bahwa need for closure dan fondasi moral memiliki pengaruh langsung yang signifikan terhadap harapan akan perdamaian. Selain itu, tidak terdapat perbedaan harapan akan perdamaian pada usia, jenis kelamin, afiliasi organisasi keagamaan, dan suku bangsa yang berbeda.
\end{abstract}

Kata Kunci: harapan, perdamaian, fondasi moral, closure kognitif

\section{Pendahuluan}

Konflik di Indonesia menunjukkan laju peningkatan setiap tahunnya. Sejak tahun 2011 sampai 2018, jumlah konflik yang terjadi meningkat dari sekitar 2.500 desa/ kelurahan menjadi sekitar 3.100 desa/ kelurahan (Sub Direktorat Statistik Politik dan Keamanan, 2017). Konflik-konflik tersebut mayoritas berkaitan dengan isu sosial berbasis agama yang pada tahun 2015 bisa mencapai 1.568 kasus (Erdianto, 2017). Dengan demikian, tidak dapat dipungkiri agama menjadi faktor konflik di masyarakat.

Meningkatnya frekuensi terjadinya konflik ini harus mendapatkan perhatian serius dari berbagai pihak, termasuk dari para peneliti. Sebab, konflik yang tidak terselesaikan bisa berdampak negatif, baik secara individual, kelompok, ataupun sosial. Menurut Böhm dkk. (2018), konflik akan menimbulkan prasangka, stereotif, rasa takut, rasa benci, agresi ataupun diskriminasi.

Meskipun konflik meningkat, tetapi tingkat risiko tindak kejahatan tampak menurun dari sekitar 140 tiap 100 ribu penduduk pada tahun 2015, hingga 113 tiap 100 ribu penduduk pada tahun 2018. Penurunan risiko tindak kejahatan ini menunjukkan peluang positif bahwa perdamaian dan resolusi konflik masih mungkin terjadi. Kemungkinan untuk berdamai tersebut memunculkan harapan akan adanya perdamaian. Harapan sendiri 
merupakan sebuah konstruk psikologis yang mendorong individu untuk memiliki tujuan, motivasi, dan strategi dalam mencapai tujuan tersebut (Snyder dkk., 1996). Dalam konteks perdamaian, harapan memiliki tujuan utama untuk menciptakan perdamaian.

Eksperimen yang dilakukan oleh Leshem dkk. (2016) menunjukkan bahwa harapan untuk perdamaian dapat mendorong deeskalasi konflik dan membangun perdamaian. Adapun faktorfaktor yang dapat membentuk harapan terhadap perdamaian diantaranya persepsi dan keyakinan bahwa dunia bisa berubah (Cohen, 2018) dan appraisal positif (Leshem \& Halperin, 2020). Namun, studistudi tersebut lebih terfokus pada konflik Palestina-Israel yang sifatnya berkepanjangan. Selain itu, peran dari aspek kognitif lain dan aspek moral masih belum dijelaskan. Studi ini bermaksud mengkaji prediktor harapan terhadap perdamaian dalam konteks Indonesia dan mempertimbangkan aspek psikologis selain persepsi dan appraisal.

Penelitian sebelumnya yang secara eksplisit mengkaji harapan terhadap perdamaian masih tergolong sedikit (Leshem dkk., 2016; Cohen-Chen \& Zomeren, 2018; Leshem \& Halperin, 2020), sehingga penulis menggunakan kajian literatur terkait gerakan damai dan tanpa kekerasan sebagai acuan dasar. Gerakan damai biasanya dikaitkan dengan aspek sosial dan politik (SenghaasKnobloch \& Volmerg, 1988), budaya, sejarah dan identitas (Liu \& Sibley, 2009), cooperation (Coleman, 2015), perilaku prososial (Schroeder \& Grazioano, 2015), keterikatan moral (Bretherton \& Law, 2015), aspek psikologi positif seperti emosi positif, kebahagiaan, kekuataan karakter, well-being, dan resiliensi (Cohrs dkk., 2013), dan spiritualitas (Walker, 2015).

Studi-studi di atas belum menjelaskan prediktor kognitif selain persepsi dan appraisal yang dapat berkontribusi pada harapan terhadap perdamaian. Salah satu prediktor kognitif yang dapat digunakan adalah need for closure yang menjelaskan tentang dorongan individu untuk mencari tahu, mendapatkan, dan memahami suatu informasi yang jelas, pasti, tidak ambigu, dan bersifat stabil (Kosic dkk., 2004). Studi sebelumnya menunjukkan bahwa need for closure memiliki efek langsung yang dimoderatori oleh competitiveness (De Zavala dkk., 2008) dan national attachment terhadap dukungan aksi militer (Federico dkk., 2005). Selain itu, need for closure juga memiliki efek tidak langsung yang dimediasi oleh ideologi terhadap perilaku konflik (De Zavala dkk., 2010). Namun, studi-studi tersebut lebih berfokus pada perilaku konflik daripada perilaku damai. Sehingga penelitian ini akan mengkaji tentang bagaimana peran need for closure dalam pembentukan harapan terhadap perdamaian.

Alasan lainnya yang melatarbelakangi fokus penelitian ini pada perdamaian adalah trend penelitian psikologi mutakhir yang memang lebih fokus pada potensipotensi positif manusia. Psikologi tidak sekedar bertugas untuk mengatasi masalahmasalah psikososial manusia, tapi juga berusaha membuat manusia lebih bahagia, bermakna, dan produktif (Seligman, 2002).

Salah satu prediktor penting yang dapat membantu menjelaskan interaksi antara need for closure dan harapan terhadap perdamaian adalah moral. Moral dapat berkontribusi pada pengambilan keputusan perilaku tertentu, baik terkait konflik ataupun sebaliknya (Lakoff, 1996). Dalam berperilaku, individu dapat menggunakan logika moral deontological (pertimbangan apakah perilaku sesuai dengan nilai yang dia anut; what is right $v s$ what is best) atau logika consequential (pertimbangan apakah perilaku sesuai dengan hasil yang diinginkan; what is right = what is best). Young dkk. (2013) menemukan bahwa individu berideologi religius fundamental dan konservatif cenderung menggunakan rule-based moral processing (logika moral deontological). 
Dengan kata lain, mereka memandang perilaku negatif sebagai pelanggaran moral.

Temuan ini menguatkan studi-studi sebelumnya yang membahas tentang pertimbangan moral pada ideologi fundamentalisme dan konservatisme. Individu fundamentalis agama cenderung memandang homoseksual dan aborsi sebagai pelanggaran moral (Layman, 1997). Senada dengan fundamentalisme, individu konservatif juga menganggap seks pranikah dan kritik terhadap pemimpin adalah tindakan tidak bermoral (Haidt \& Graham, 2007).

Namun, Ditto dan Liu (2016) menyebutkan bahwa orang konservatif cenderung menggunakan logika consequential. Perbedaan ini disebabkan Young dkk. (2013) membahas dilema moral pada isu-isu yang bersifat umum sedangkan Ditto dan Liu (2016) lebih fokus pada pandangan orang konservatif terhadap kelompoknya. Orang yang liberal atau mendukung multikulturalisme memaklumi kesalahan outgroup yang tidak disengaja (consequential), dan mempertimbangkan nilai-nilai saat ingroup-nya yang melakukan kesalahan (deontological) sedangkan konservatif memaklumi keduaduanya (consequential). Hal ini disebabkan salah satu moral hotspot (pemicu tindakan) individu berideologi liberal adalah isu tentang kelompok minoritas.

Dalam kaitannya dengan need for closure, studi Kossowska dkk. (2016) menunjukkan bahwa need for closure dapat berkontribusi pada keputusan moral. Selain itu, terdapat hubungan antara cognitive closure dan binding morality yang dimediasi oleh ideologi politik (Federico dkk., 2016). Konstruk moral lain yang dapat dipertimbangkan adalah fondasi moral. Graham dkk. (2012) mengembangkan teori fondasi moral yang terbagi menjadi 5 yakni harm/ care, fairness/ reciprocity, ingroup/ loyalty, respect/ authority, dan purity/ sanctity. Kelima fondasi moral tersebut juga dapat diklasifikasikan menjadi dua kelompok yakni binding (purity, respect, dan loyalty) serta individualizing moral foundations (harm dan fairness). Malka dkk. (2016) menemukan bahwa hubungan antara ideologi konservatif dengan isu-isu moralitas tradisional menguat pada individu dengan binding foundations dan disgust sensitivity yang tinggi.

Studi sebelumnya menunjukkan bahwa fondasi moral dapat memediasi pengaruh ideologi terhadap kompleksitas kognitif dan tindakan terkait moral (Joseph dkk., 2009). Studi lain juga menemukan bahwa terdapat hubungan antara fondasi moral dan cognitive style (Hannikainen dkk., 2017). Fondasi moral berperan dalam hubungan antara cognitive closure dengan dukungan terhadap hukuman yang terdiri dari utilitarian yang fokus pada pencegahan dan retributive yang fokus untuk membalas perbuatan (Giacomantonio dkk., 2017). Studi lain menambahkan peran dari moral exclusion sebagai mediator dalam hubungan relatif fondasi moral dan kecenderungan tindakan yang bersifat positif atau negatif (Hadarics \& Kende, 2018).

Berdasarkan uraian di atas, terlihat bahwa aspek kognitif dan moral dapat mendorong munculnya harapan terhadap perdamaian. Sehingga pertanyaan penelitian ini adalah bagaimana interaksi antara need for closure, fondasi moral, dan harapan untuk perdamaian. Penelitian ini akan menguji peran need for closure dan fondasi moral secara langsung dan tidak langsung terhadap harapan untuk perdamaian. Selain itu, keterkaitan variabel tersebut dengan data demografis, yakni jenis kelamin, usia, suku bangsa, dan afiliasi keagamaan juga dibandingkan.

\section{Metode Penelitian}

Penelitian ini merupakan penelitian kuantitatif dengan analisis korelasional. Respondennya adalah 385 mahasiswa di sebuah universitas Islam di kota Bandung. Teknik sampling yang digunakan adalah convenience sampling. Terdapat 11 
partisipan yang jawabannya tidak lengkap sehingga partisipan yang dapat dianalisis berjumlah 374 orang. Data responden berdasarkan jenis kelamin, suku bangsa, dan afiliasi organisasi keagamaan disajikan pada tabel 1, 2, dan 3 .

\section{Variabel dan Pengukuran}

Terdapat tiga variabel dalam penelitian ini yakni harapan untuk perdamaian sebagai variabel terikat dan need for closure dan fondasi moral sebagai variabel prediktor.

\section{Harapan untuk perdamaian}

Variabel terikat dalam penelitian ini adalah harapan terhadap perdamaian. Untuk mengukurnya, peneliti menggunakan skala harapan yang diadaptasi ke dalam konteks perdamaian (Snyder dkk., 1996). Alat ukur tersebut berbentuk skala Likert dari 1 (sangat salah) sampai dengan 4 (sangat benar) untuk merespon pernyataan seperti: "Saya dapat memikirkan banyak cara untuk menyelesaikan suatu konflik".

Tabel 1

Jumlah Responden berdasarkan Jenis Kelamin

\begin{tabular}{lcc}
\hline \multicolumn{1}{c}{ Responden } & Jumlah & Persentase \\
\hline Pria & 129 & $34.5 \%$ \\
Wanita & 245 & $65.5 \%$ \\
\hline
\end{tabular}

Tabel 2

Jumlah Responden berdasarkan Suku Bangsa

\begin{tabular}{lcc}
\hline \multicolumn{1}{c}{ Responden } & Jumlah & Persentase \\
\hline Sunda & 269 & $71.9 \%$ \\
Jawa & 58 & $15.5 \%$ \\
Lainnya & 47 & $12.6 \%$ \\
\hline
\end{tabular}

Tabel 3

Jumlah Responden Berdasarkan Afiliasi Organisasi Keagamaan

\begin{tabular}{lcc}
\hline \multicolumn{1}{c}{ Responden } & Jumlah & Persentase \\
\hline NU & 234 & $62.6 \%$ \\
Persis & 53 & $14.2 \%$ \\
Muhammadiyah & 37 & $9.9 \%$ \\
Lainnya & 50 & $13.4 \%$ \\
\hline
\end{tabular}

Skala ini terdiri dari 6 item yang mengukur aspek agency dan pathway dari harapan dan 3 item distractor (total 9 item). Skala ini memiliki tingkat reliabilitas sebesar .731 (p>.70) sehingga dapat dikatakan bahwa alat ukur ini memiliki reliabilitas tinggi.

\section{Need for closure}

Pengukuran need for closure menggunakan skala 15 item yang dikembangkan oleh Roets dan Hiel (2011). Pilihan respon mulai dari 1 (sangat tidak setuju) sampai dengan 6 (sangat setuju) disediakan untuk merespon pernyataan seperti, "Saya tidak suka situasi yang tidak pasti". Reliabilitas alat ukur ini tinggi yakni .736 .

\section{Fondasi moral}

Pengukuran fondasi moral menggunakan Moral Foundation Questionnaire atau MFQ (Graham dkk., 2011). Kuesioner ini terdiri dari 2 bagian yang terbagi masing-masing 16 item (total 32 item). Skala Likert 1 (sangat tidak setuju/ sama sekali tidak relevan) hingga 5 (sangat setuju/ sangat relevan) digunakan untuk merespon pernyataan seperti "Keadilan adalah syarat paling penting untuk suatu masyarakat". MFQ memiliki reliabilitas tinggi sebesar .788.

\section{Prosedur}

Distribusi kuesioner dilakukan dengan menyebarkan undangan pada partisipan melalui media sosial dan kontak secara langsung dalam kurun waktu 2 minggu. Partisipan yang bersedia kemudian mengisi kuesioner yang berisi informed consent, data demografis dan pengukuran variabel. Kerahasiaan data dijamin dengan menjaga anonimitas partisipan. Setelah 2 minggu, terkumpul 385 partisipan yang kemudian diproses untuk analisis menjadi 374 partisipan.

\section{Analisis Data}

Untuk menguji interaksi ketiga variabel, dilakukan analisis jalur (path analysis) yang merupakan kelanjutan dari uji regresi. Adapun uji korelasi Pearson 
digunakan untuk mengetahui lebih spesifik mengenai dinamika hubungan lima aspek fondasi moral dengan need for closure dan harapan untuk perdamaian. Untuk mengetahui apakah terdapat perbedaan pada kondisi demografis yang berbeda, dilakukan uji beda menggunakan t-test dan ANOVA. Uji-uji tersebut dilakukan menggunakan software SPSS.

\section{Hasil Penelitian dan Pembahasan}

\section{Peran Need for Closure dan Fondasi Moral terhadap Harapan untuk Perdamaian}

Setelah dilakukan analisis, pada gambar 1 terbukti bahwa need for closure maupun fondasi moral dapat berpengaruh secara signifikan terhadap harapan untuk perdamaian. Berdasarkan output hasil uji diketahui bahwa secara langsung terdapat pengaruh signifikan dari need for closure terhadap harapan untuk perdamaian $(\beta=$ $.219, \mathrm{p}<.01)$. Temuan ini mengindikasikan bahwa need for closure tidak hanya berkontribusi terhadap konstruk terkait konflik (De Zavala dkk., 2010), tetapi juga konstruk terkait perdamaian yang dalam studi ini direpresentasikan oleh harapan untuk perdamaian. Hal ini sejalan dengan penelitian Kossowska dkk. (2016) yang menunjukkan bahwa need for closure dapat mengarahkan sikap positif dan mengurangi stereotype terhadap outgroup ketika individunya tidak mampu mencapai closure yang dibutuhkan.

Selain itu, hasil uji juga memperlihatkan bahwa secara langsung terdapat pengaruh signifikan fondasi moral terhadap harapan untuk perdamaian $(\beta=.285, \mathrm{p}<$ $.01)$. Temuan ini mengindikasikan bahwa fondasi moral dapat mendorong peningkatan harapan terhadap perdamaian. Hal ini mengkonfirmasi studi sebelumnya mengenai adanya peran fondasi moral pada pemilihan tindakan yang bersifat positif $v s$ negatif (Hadarics \& Kende, 2018). Selain itu, fondasi moral terbukti berperan dalam hubungan antara ideologi, kompleksitas kognitif, dan tindakan moral (Joseph dkk., 2009).

Gambar 1 memperlihatkan pengaruh tidak langsung need for closure melalui fondasi moral terhadap harapan untuk perdamaian yaitu: $.213 \times .285=.06$. Temuan ini memperlihatkan bahwa pengaruh langsung need for closure terhadap harapan untuk perdamaian (.219) lebih besar dibandingkan dengan pengaruh tidak langsungnya (.06). Dengan demikian, pengaruh need for closure terhadap harapan untuk perdamaian tidak memerlukan fondasi moral sebagai mediator. Hasil tersebut berbeda dengan studi Giacomantonio dkk. (2017) yang menyebutkan bahwa fondasi moral memediasi cognitive closure dengan dukungan terhadap hukuman. Dengan kata lain, baik itu need for closure maupun fondasi moral adalah dua faktor yang berdiri sendiri dalam memberikan dampak terhadap harapan untuk perdamaian.

Need for closure (NfC) merupakan salah satu prediktor rasa khawatir akan tindak kejahatan (Jackson, 2015). Adanya need for closure mampu meningkatkan sensitivitas pada perilaku kriminal, sehingga dapat membuat orang lebih kuat

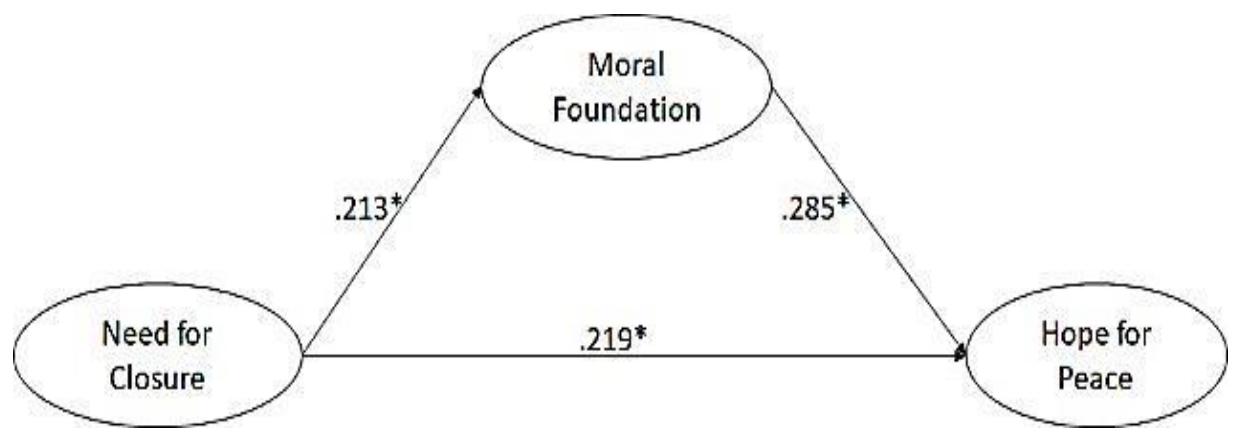

Gambar 1. Model analisis jalur need for closure, fondasi moral, dan harapan untuk perdamaian. 
untuk menghindarinya. Dalam sudut pandang perdamaian, maka menjadi masuk akal ia berkorelasi dengan harapan untuk perdamaian, karena situasi damai dapat pula diidentikkan dengan keadaan meningkatnya sensitivitas kelompok terhadap aturan-aturan yang maslahat bagi kepentingan bersama, sehingga mengurangi peluang terjadinya tindak kriminalitas.

Penelusuran lebih lanjut tentang NfC menghasilkan temuan-temuan yang menarik. NfC pada beberapa kondisi dapat membuat seseorang kukuh bertahan pada keadaan asal. Dengan demikian, NfC dapat memiliki peran sebagai pembatas sosiopsikologis dalam tercapainya perdamaian, dimana kondisi damai tersebut adalah sesuatu yang belum terjadi (Halperin \& Bar-Tal, 2011). Artinya, situasi konflik yang merupakan situasi asal dapat dipilih karena peran NfC itu sendiri.

Temuan lain menunjukkan, NfC di satu sisi mampu menjadi penghubung terciptanya perdamaian, namun di sisi lain dapat menjadi trigger tindakan ekstrimisme pada peristiwa terorisme. Studi Webber dkk. (2018) menunjukkan terorisme berkaitan dengan kegagalan seseorang membentuk diri yang signifikan. Pengalaman kegagalan ini semakin mengarahkan pada tindakan ekstrimisme melalui faktor NfC. Dalam hal ini, kepastian yang dimaksud adalah upaya membentuk diri menjadi signifikan.

Dengan demikian, konteks kepastian yang dimaksud pada studi tentang harapan akan perdamaian juga perlu dikaji secara mendalam. Begitu pula faktor-faktor kontekstual, seperti halnya kesehatan, kesejahteraan, pendidikan, juga faktor historis lingkungan hendaknya menjadi variabel yang turut dianalisa pada riset-riset ke depan. Lalu dalam kaitannya dengan moral foundation, membangun perdamaian berkaitan dengan pendekatan filosofis pada berbagai macam lapisan masyarakat terkait. Nilai-nilai filosofis selalu berkaitan dengan upaya terciptanya perdamaian (Snauwaert, 2014; Taylor, 2010). Nilai filosofis tidak bisa dilepaskan dari pembentukan moral, maka hal ini menjadi salah satu alasan logis keberadaan moral tidak dapat terpisahkan dari upaya mendorong terciptanya perdamaian.

Perdamaian yang melibatkan keberadan pihak lain di luar kelompok sendiri, membutuhkan kepekaan diri terhadap sudut pandang apapun tentang kelompok luar. Dalam hal ini, moral memiliki peranan kembali, karena secara psikologis internalisasi personal nilai-nilai moral mampu meluaskan pandangan akan keberadaan pihak atau kelompok lain (Kertzer dkk., 2015). Keberadaan fondasi moral semakin penting dalam kaitannya dengan harapan untuk perdamaian, karena moral mampu memberi ruang seseorang melihat diri dalam posisi yang berbeda (tidak hanya pada sudut pandang kelompok sendiri), sehingga membentuk koneksi antar perbedaan-perbedaan yang ada (Koleva dkk., 2012).

Adapun hasil uji korelasi Pearson bisa dilihat pada tabel 4, yang menunjukkan bahwa kelima aspek fondasi moral memiliki hubungan yang signifikan dengan harapan untuk perdamaian, dimana korelasi paling kuat terdapat pada aspek ingroup/ loyalty $(\mathrm{r}=.252, \mathrm{p}<.01)$. Hasil ini berbeda dengan studi sebelumnya dalam konteks gerakan lingkungan, dimana aspek fairness/ reciprocity yang paling berpengaruh pada keinginan untuk melakukan perubahan (Dickinson dkk., 2016).

Tabel 4

Korelasi Need for Closure dan Harapan untuk Perdamaian dengan Fondasi Moral per Domain

\begin{tabular}{lcc}
\hline \multicolumn{1}{c}{$\begin{array}{c}\text { Domain fondasi } \\
\text { moral }\end{array}$} & $\begin{array}{c}\text { Hope for } \\
\text { peace }\end{array}$ & $\begin{array}{c}\text { Need for } \\
\text { closure }\end{array}$ \\
\hline Harm/ Care & $.210^{*}$ & $.156^{*}$ \\
Fairness/ Reciprocity & $.215^{*}$ & $.183^{*}$ \\
Ingroup/ Loyalty & $.252^{*}$ & $.169^{*}$ \\
Authority/ Respect & $.172^{*}$ & .093 \\
Purity/ Sanctity & $.209^{*}$ & $.187^{*}$ \\
\hline$* \mathrm{p}<.05$ & &
\end{tabular}


Pada tabel 4 juga dikemukakan, terdapat pengaruh signifikan need for closure terhadap fondasi moral $(\beta=.213, \mathrm{p}$ $<.01)$. Temuan ini sejalan dengan studi sebelumnya yang menunjukkan bahwa terdapat hubungan antara fondasi moral dan cognitive style (Hannikainen dkk., 2017). Selain itu, aspek-aspek fondasi moral menunjukkan hubungan signifikan dengan need for closure kecuali aspek authority/ respect. Aspek fondasi moral yang memiliki korelasi paling kuat dengan need for closure adalah aspek purity/ sanctity. Hasil ini sesuai dengan studi Rahman (2017) yang menyebutkan bahwa domain moral kesucian berpengaruh terhadap kemunafikan.

\section{Perbandingan Data Demografis}

Hasil uji $t$ test menunjukkan bahwa tidak terdapat perbedaan rata-rata skor fondasi moral pada jenis kelamin yang berbeda. Adapun hasil ANOVA menunjukkan bahwa terdapat perbedaan rata-rata pada domain fondasi moral tertentu berdasarkan usia, suku, dan organisasi keagamaan. Skor domain authority/ respect menjadi berbeda pada usia yang berbeda $[F(7.366)=2.09, p=$ .044]. Skor tertinggi berada pada usia 23 tahun dan skor terendah ada pada usia 18 tahun. Hal ini menunjukkan bahwa semakin dewasa seseorang, domain fondasi moral authority/ respect yang dimiliki juga semakin kuat.

Pada suku bangsa yang berbeda, domain ingroup/loyalty $[F(10.363)=2.68$, $p<.05]$ dan purity/ sanctity juga menunjukkan perbedaan $[F(10.363)=$ $2.71, \mathrm{p}<.05]$. Selain itu, pada organisasi keagamaan yang berbeda, terdapat perbedaan pada domain purity/ sanctity. Hasil tersebut mendukung studi Rahman (2017) yang menggarisbawahi peran penting dari purity/ sanctity.

Terkait need for closure dan harapan untuk perdamaian tidak ditemukan perbedaan signifikan terkait usia, jenis kelamin, dan organisasi keagamaan.
Namun, terdapat perbedaan need for closure pada suku yang berbeda $[F$ $(10.363)=2.74, p<.05]$. Temuan-temuan di atas mengindikasikan bahwa fondasi moral purity/ sanctity dan suku bangsa tampak memiliki keterkaitan dengan need for closure. Selain itu, perbedaan usia juga tampak memiliki keterkaitan dengan fondasi moral individu.

\section{Simpulan}

Berdasarkan temuan penelitian, baik need for closure maupun fondasi moral dapat menjadi faktor yang meningkatkan harapan untuk perdamaian dalam diri seseorang. Kedua variabel tersebut dapat menjadi salah satu alternatif langkah dalam upaya mempromosikan perdamaian. Penelitian ini menegaskan bahwa membentuk harapan untuk perdamaian dapat melibatkan, baik itu aspek kognitif maupun moral seseorang. Artinya, upaya mempromosikan perdamaian selalu melibatkan berbagai macam sisi psikologis manusia. Keduanya dibutuhkan dalam membentuk perdamaian dalam relasi masyarakat dengan berbagai kompleksitasnya.

\section{Daftar Pustaka}

Böhm, R., Rusch, H., \& Baron, J. (2018). The psychology of intergroup conflict: A review of theories and measures. Journal of Economic Behavior and Organization, 2018. 1-16. https://doi.org/10.1016/j.jebo.2018.01. 020

Bretherton, D., \& Law, S. F. (Eds.). (2015). Methodologies in peace psychology: Peace research by peaceful means (Vol. 26). Springer.

Cohen-Chen, S., \& Van Zomeren, M. (2018). Yes we can? Group efficacy beliefs predict collective action, but only when hope is high. Journal of Experimental Social Psychology, 77, 50-59. https://doi.org/ 10.1016/j.jesp.2018.03.016 
Cohrs, J. C., Christie, D. J., White, M. P., \& Das, C. (2013). Contributions of positive psychology to peace: Toward global well-being and resilience. American Psychologist, 68(7), 590600. https://doi.org/10.1037/a0032089

Coleman, P. T. (2015). Morton Deutsch: A pioneer in developing peace psychology. Springer International Publishing.

De Zavala, A. G. D., Cislak, A., \& Wesolowska, E. (2010). Political conservatism, need for cognitive closure, and intergroup hostility. Political Psychology, 31(4), 521-541. https://doi.org/10.1111/j.14679221.2010.00767.x

De Zavala, A. G., Federico, C. M., Cisłak, A., \& Sigger, J. (2008). Need for closure and competition in intergroup conflicts: Experimental evidence for the mitigating effect of accessible conflict-schemas. European journal of social psychology, 38(1), 84-105. https://doi.org/10.1002/ejsp.438

Ditto, P. H., \& Liu, B. S. (2016). Moral coherence and political conflict. In Valdesolo \& Graham (Eds.) Social psychology of political polarization (pp. 102-122). Psychology Press.

Dickinson, J. L., McLeod, P., Bloomfield, R., \& Allred, S. (2016). Which moral foundations predict willingness to make lifestyle changes to avert climate change in the USA? PloS one, 11(10). https://doi.org/10.1371/journal.pone.01 63852

Erdianto, K. (2017, Maret 15). Kelompok radikal berbasis agama jadi faktor terjadinya konflik sosial. Kompas.com. https://nasional.kompas.com/read/2017 /03/15/13385681/kelompok.radikal.ber basis.agama.jadi.faktor.terjadinya.konfl ik.sosial

Federico, C. M., Golec, A., \& Dial, J. L. (2005). The relationship between the need for closure and support for military action against Iraq: Moderating effects of national attachment. Personality and Social Psychology Bulletin, 31(5), 621-632. https://doi.org/10.1177/014616720427 1588

Federico, C. M., Ekstrom, P., Tagar, M. R., \& Williams, A. L. (2016). Epistemic motivation and the structure of moral intuition: Dispositional need for closure as a predictor of individualizing and binding morality. European Journal of Personality, 30, 227-239. https://doi.org/10.1002/per.2055

Giacomantonio, M., Pierro, A., Baldner, C., \& Kruglanski, A. (2017). Need for closure, torture, and punishment motivations. Social Psychology, 48, 335-347. https://doi.org/10.1027/18649335/a000321

Graham, J., Nosek, B. A., Haidt, J., Iyer, R., Koleva, S., \& Ditto, P. H. (2011). Mapping the moral domain. Journal of Personality and Social Psychology, 101(2), 366-385. https://doi.org/10.1037/a0021847

Grussendorf, J., McAlister, A., Sandström, P., Udd, L., \& Morrison, T. C. (2002). Resisting moral disengagement in support for war: Use of the "Peace Test" scale among student groups in 21 nations. Peace and Conflict: The Journal of Peace Psychology, 8, 73-83. https://doi.org/10.1207/S15327949PA C0801_7

Hadarics, M., \& Kende, A. (2018). Moral foundations of positive and negative intergroup behavior: Moral exclusion fills the gap. International Journal of Intercultural Relations, 64, 67-76. https://doi.org/10.1016/j.ijintrel.2018.0 3.006

Haidt, J., \& Graham, J. (2007). When morality opposes justice: Conservatives have moral intuitions that liberals may not recognize. Social Justice Research, 20(1), 98-116. https://doi.org/10.1007/s11211-0070034-z 
Halperin, E., \& Bar-tal, D. (2011). Sociopsychological barriers to peace making: An empirical examination within the Israeli Jewish society. Journal of Peace Research, 48(5), 637651.

https://doi.org/10.1177/002234331141 2642

Hannikainen, I. R., Miller, R. M., \& Cushman, F. A. (2017). Act versus impact: Conservatives and liberals exhibit different structural emphases in moral judgment. Ratio, 30(4), 462-493.

Hayhurst, L. M. C., \& Giles, A. (2013). Private and moral authority, selfdetermination, and the domestic transfer objective: Foundations for understanding sport for development and peace in aboriginal communities in Canada. Sociology of Sport Journal, 30, 504-519. https://doi.org/10.1123/ssj.30.4.504

Jackson, J. (2015). Cognitive closure and risk sensitivity in the fear of crime. Legal and Criminological Psychology, 20(2), 222-240. https://doi.org/10.1111/lcrp.12031

Jackson, L. E., \& Sparr, J. L. (2005). Introducing a new scale for the measurement of moral disengagement in peace and conflict research. Conflict \& Communication Online, 4(2), 1-16.

Joseph, C. M., Graham, J., \& Haidt, J. (2009). The end of equipotentiality: A moral foundations approach to ideology-attitude links and cognitive complexity. Psychological Inquiry, 20(2-3), 172-176. https://doi.org/10.1080/104784009030 88882

Kosic, A., Kruglanski, A. W., Pierro, A., \& Mannetti, L. (2004). The social cognition of immigrants' acculturation: effects of the need for closure and the reference group at entry. Journal of Personality and Social Psychology, 86(6), 796. https://doi.org/10.1037/00223514.86.6.796
Kertzer, J. D., Powers, K. E., Rathbun, B. C., \& Iyer, R. (2015). Moral support: How moral values shape foreign. Journal of Politics, 76(3), 825-840. https://doi.org/10.1017/S00223816140 00073

Koleva, S. P., Graham, J., Iyer, R., Ditto, P. H., \& Haidt, J. (2012). Tracing the threads: How five moral concerns (especially purity) help explain culture war attitudes. Journal of Research in Personality, 46(2), 184-194. https://doi.org/10.1016/j.jrp.2012.01.00 6

Kossowska, M., Czernatowicz-Kukuczka, A., Szumowska, E., \& Czarna, A. (2016). Cortisol and moral decisions among young men: The moderating role of motivation toward closure. Personality and Individual Differences, 101, 249-253 https://doi.org/10.1016/j.paid.2016.06. 017

Kruglanski, A. W., \& Webster, D. M. (1996). Motivated closing of the mind: "Seizing" and "freezing". Psychological Review, 103, 263-283.

Lakoff, G. (1996). What conservatives know that liberals don't. University of Chicago Press.

Layman, G. C. (1997). Religion and political behavior in the United States: The impact of beliefs, affiliations, and commitment from 1980 to 1994. Public Opinion Quarterly, 61(2), 288316. https://doi.org/10.1086/297796

Leshem, O. A. (2017). What you wish for is not what you expect: Measuring hope for peace during intractable conflicts. International Journal of Intercultural Relations, 60, 60-66. http://doi.org/10.1016/j.ijintrel.2017.06 .005

Leshem, O. A. (2019). The pivotal role of the enemy in inducing hope for peace. Political Studies, 67(3), 693-711.

Leshem, O. A., \& Halperin, E. (2020). Hoping for peace during protracted conflict: Citizens' hope is based on 
inaccurate appraisals of their adversary's hope for peace. Journal of Conflict Resolution, 1-28. https://doi.org/10.1177/002200271989 6406

Leshem, O. A., Klar, Y., \& Flores, T. E. (2016). Instilling hope for peace during intractable conflicts. Social Psychological and Personality Science, 7(4), 303-311. https://doi.org/10.1177/194855061562 6776

Liu, J. H., \& Sibley, C. G. (2009). Culture, social representations, and peacemaking: A symbolic theory of history and identity. Dalam C. J. Montiel \& N. M. Noor (Eds.), Peace psychology in Asia (pp. 21-39). Springer.

Malka, A., Osborne, D., Soto, C. J., Greaves, L. M., Sibley, C. G., \& Lelkes, Y. (2016). Binding moral foundations and the narrowing of ideological conflict to the traditional morality domain. Personality and Social Psychology Bulletin, 42(9), 1243-1257.

https://doi.org/10.1177/014616721665 3936

Pilisuk, M. (2005). Is there really hope for peace? Peace and conflict. Journal of Peace Psychology, 11(4), 419-425. https://doi.org/10.1207/s15327949pac1 104_8

Rahman, A. A. (2017). Regulasi Perilaku Islami, Kesadaran Moral, dan Kemunafikan. Jurnal Psikologi, 13(1), 65-72. http://doi.org/10.24014/jp.v13i1.3092

Roets, A., \& Hiel, A. V. (2011). Item selection and validation of a brief, 15item version of the need for closure scale. Personality and Individual Differences, 50(1), 90-94.

Schroeder, D. A., \& Graziano, W. G. (Eds.). (2015). The Oxford handbook of prosocial behavior. Oxford Library of Psychology.

Seligman, M. E. P. (2002). Positive psychology, positive prevention, and positive therapy. Dalam C. R. Snyder \& S. J. Lopez (Eds.), Handbook of positive psychology. Oxford University Press.

Senghaas-Knobloch, E., \& Volmerg, B. (1988). Towards a social psychology of peace. Journal of Peace Research, 25(3), 245-256. https://doi.org/10.1177\%2F002234338 802500304

Snauwaert, D. (2014). Social justice and the philosophical foundations of critical peace education: Exploring Nussbaum, Sen, and Freire. Journal of Peace Education, 8(3), 315-331. https://doi.org/10.1080/17400201.2011 .621371

Snyder, C. R., Sympson, S. C., Ybasco, F. C., Borders, T. F., Babyak, M. A., \& Higgins, R. L. (1996). Development and validation of the state hope scale. Journal of Personality and Social Psychology, 70(2), 321-335. https://doi.org/10.1037/00223514.70.2.321

Staats, S., \& Partlo, C. (1993). A brief report on hope in peace and war, and in good times and bad. Social Indicators Research, 29(2), 229-243. https://doi.org/10.1007/BF01077897

Sub Direktorat Statistik Politik dan Keamanan. (2017). Statistik kriminal 2017. Badan Pusat Statistik.

Taylor, R. S. (2010). Kant's political religion: The transparency of perpetual peace and the highest good. The Review of Politics, 72(1), 1-24. https://doi.org/10.1017/S00346705099 90945

Walker, P. O. (2015). Indigenous paradigm research. Dalam D. Bretherton \& S. F. Law (Eds.), Methodologies in peace psychology (pp. 159-175). Springer.

Watkins, M. M. (1985). Moral imagination and peace activism: Discerning the inner voices. Psychological Perspectives, 16(1), 77-93. 
https://doi.org/10.1080/003229285084 07945

Webber, D., Babush, M., Schori-Eyal, N., Vazeou-Nieuwenhuis, A., Hettiarachchi, M., Bélanger, J. J., Moyano, M., Trujillo, H. M., Gunaratna, R., Kruglanski, A. W., \& Gelfand, M. J. (2018). The road to extremism: Field and experimental evidence that significance loss-induced need for closure fosters radicalization. Journal of Personality and Social Psychology, 2(114), 270-285. https://doi.org/10.1037/pspi0000111

Young, O., Willer, R., \& Keltner, D. (2013). "Thou shalt not kill": Religious fundamentalism, conservatism, and rule-based moral processing. Psychology of Religion and Spirituality, 5(2), 110-115. https://doi.org/10.1037/a0032262 
Psympathic, Jurnal Ilmiah Psikologi Juni 2020, Vol. 7, No. 1, Hal. : 93-104 